UDC 624.04

\title{
MODAL ANALYSIS OF REINFORCED CONCRETE AND FIBER CONCRETE BEAMS
}

\author{
T. Makovkina ${ }^{1}$, M. Surianinov ${ }^{1}$, O. Chuchmai ${ }^{1}$ \\ ${ }^{1}$ Odesa state academy of civil engineering and architecture
}

\begin{abstract}
Analytical, experimental and numerical results of determination of natural frequencies and forms of oscillations of reinforced concrete and fiber concrete beams are given. Modern analytical, numerical and experimental methods of studying the dynamics of reinforced concrete and fiber concrete beams are analyzed. The problem of determining the natural frequencies and forms of oscillations of reinforced concrete and fiber concrete beams at the initial modulus of elasticity and taking into account the nonlinear diagram of deformation of materials is solved analytically. Computer modeling of the considered constructions in four software complexes is done and the technique of their modal analysis on the basis of the finite element method is developed. Experimental researches of free oscillations of the considered designs and the comparative analysis of all received results are carried out. It is established that all involved complexes determine the imaginary frequency and imaginary form of oscillations. The frequency spectrum calculated by the finite element method is approximately $4 \%$ lower than that calculated analytically; the results of the calculation in SOFiSTiK differ by $2 \%$ from the results obtained in the PC LIRA; the discrepancy with the experimental data reaches $20 \%$, and all frequencies calculated experimentally, greater than the frequencies calculated analytically or by the finite element method. This rather significant discrepancy is explained, according to the authors, by the incorrectness of the used dynamic model of the reinforced beam. The classical dynamics of structures is known to be based on the theory of linear differential equations, and the oscillations of structures are considered in relation to the unstressed initial state. It is obvious that in the study of free and forced oscillations of reinforced concrete building structures such an approach is unsuitable because they are physically nonlinear systems. The concept of determining the nonlinear terms of these equations is practically not studied. Numerous experimental researches and computer modeling for the purpose of qualitative and quantitative detection of all factors influencing a spectrum of natural frequencies of fluctuations are necessary here.
\end{abstract}

Keywords: beam, concrete, fiber concrete, dynamics, modal analysis, oscillation frequency, oscillations shape, model, finite element method, PC LIRA-SAPR, ANSYS

\section{МОДАЛЬНИЙ АНАЛІЗ ЗАЛІЗОБЕТОННИХ ТА ФІБРОБЕТОННИХ БАЛОК}

\author{
Маковкіна Т. С. ${ }^{1}$, Сур'янінов М. Г. ${ }^{\mathbf{1}}$, Чучмай О. М. ${ }^{\mathbf{1}}$ \\ ${ }^{1}$ Одеська державна академія будівниџтва та архітектури
}

Анотація. Наведені аналітичні, експериментальні та чисельні результати визначення власних частот i форм коливань залізобетонних та фібробетонних балок. Проаналізовані сучасні аналітичні, чисельні та експериментальні методи дослідження динаміки залізобетонних та фібробетонних балок. Розв'язано аналітично задачу визначення власних частот і форм коливань залізобетонних та фібробетонних балок при початковому модулі пружності та 3 урахуванням нелінійної діаграми деформування матеріалів. Виконано комп'ютерне моделювання розглянутих конструкцій у чотирьох програмних комплексах і розроблено методику їх модального аналізу на базі методу скінчених елементів. Виконані експериментальні дослідження вільних коливань розглянутих конструкцій та здійснений порівняльний аналіз усіх отриманих результатів. Встановлено, що усі задіяні комплекси визначають уявну частоту і уявну форму коливань. Спектр частот, обчислений методом скінчених елементів, приблизно на $4 \%$ нижчий, чим обчислений аналітично; результати розрахунку в SOFiSTiK на 2 \% відрізняються від результатів, отриманих в ПК ЛIPA; 
розбіжність з експериментальними даними досягає $20 \%$, причому, усі частоти, обчислені експериментально, більші частот, обчислених аналітично або методом скінчених елементів. Така досить значна розбіжність пояснюється, на думку авторів, некоректністю використовуваної динамічної моделі армованої балки. Класична динаміка споруд, як відомо, грунтується на теорії лінійних диференціальних рівнянь, а коливання конструкцій розглядаються щодо ненапряженого вихідного стану. Очевидно, що при дослідженні вільних і вимушених коливань залізобетонних будівельних конструкцій такий підхід непридатний, оскільки вони $є$ фізично нелінійними системами. Концепція визначення нелінійних членів цих рівнянь практично не вивчена. Тут необхідні численні експериментальні дослідження та комп'ютерне моделювання 3 метою якісного і кількісного виявлення всіх факторів, що впливають на спектр власних частот коливань.

Ключові слова: балка, бетон, фібробетон, динаміка, модальний аналіз частота коливань, форма коливань, модель, метод скінчених елементів, ПК ЛIPA-CAПР, ANSYS 


\section{INTRODUCTION}

A large number of both theoretical and experimental works of domestic and foreign scientists are devoted to the study of the behavior of reinforced concrete structures under the static action of external loads. Problems of dynamics of beams, however, as well as other reinforced concrete structures, are covered much worse.

This state is obviously explained by the fact that the dynamic calculations of reinforced concrete structures are associated with the solution of a range of issues: determining the parameters of dynamic loads; limit states and methods of their rationing; accounting for changes in strength characteristics and deformable characteristics of concrete and reinforcement; determination of forces in constructions, etc.

A significant contribution to the nature of changes in the dynamic parameters of reinforced concrete structures is the nature of reinforcement. This fact is well known, but has not yet been thoroughly studied either quantitatively or qualitatively.

Some authors argue, for example, that the real contribution of reinforcing concrete beams is several times higher than the contribution obtained by calculations according to existing theoretical methods. And the influence of dispersed reinforcement, in particular, steel fiber, on the dynamic parameters has been studied even less. Incidentally, to increase the fracture toughness, many researchers suggest using steel fiber. Steel fiber concrete is effective in construction in earthquake-prone areas due to increased resistance to dynamic loads [1-2]. Despite the growing interest in reinforced concrete and the corresponding increase in publications, the available data are contradictory, have some incompleteness, which allows us to give only a general assessment of the results presented in them.

When solving almost any problem of dynamics there is a need to determine the natural frequencies and forms of oscillations (or, as they say, modal analysis of the system), which is natural, because these parameters determine the behavior of the system and other types of dynamic influences. With regard to structures made of materials with a linear nature of deformation, many practically important problems have been solved. But the dynamics of structures made of reinforced concrete and fiber concrete - materials with a nonlinear deformation pattern - is obviously not sufficiently studied. Therefore, research in this direction is actual.

\section{REFERENCE ANALYSIS AND PROBLEM FORMULATION}

The number of publications on this topic should be considered quite limited. Papers [3, 4] present the results of experimental studies of reinforced concrete beams on supports with different stiffness under transverse static and short-term dynamic loading. The resistance of structures on inclined sections at different span of the cut is considered.

In [5] the solution of the problem of strength of reinforced concrete beams under the action of transverse and longitudinal dynamic loads is given. Theoretical studies of the stressstrain state in the cross section of a rectilinear beam structure loaded transversely evenly distributed by dynamic loading and longitudinal compressive forces are performed. Dynamic loads change over time according to given laws. At loading the advance entry of one loading in relation to another is possible. The structure performs oscillations (longitudinal and transverse), which may be accompanied by multiple changes in the sign of deformation.

In [6] a comparison of these experiments to determine the frequencies of natural oscillations of reinforced concrete beams with cracks according to the method developed on the numerical-analytical version of BEM using diagrams of deformation of sections constructed using SNiP 2.03.01-84 [7]. 
The destruction of reinforced concrete columns and beams under impulse loading is numerically and experimentally studied in [8]. The behavior of concrete is described taking into account the different mechanical and strength characteristics of the material in tension and compression. The behavior of steel reinforcement is modeled by an elastic-plastic medium. Numerical simulation is performed by the finite element method in a threedimensional formulation.

In [9] experimental researches of the reinforced concrete elements having zone reinforcement from steel fiber in a compressed zone of section and strong reinforcement in the stretched zone, at short-term dynamic bending are carried out. New experimental data characterizing the process of resistance of steel-reinforced concrete elements with mixed reinforcement are obtained, the peculiarities of deformation, crack formation and destruction of such structures under intensive dynamic loading are revealed. Prerequisites and method of calculation of bending steel-reinforced concrete structures with mixed reinforcement at shortterm dynamic loading are formulated.s

The ratio of elastic moments, deflections and frequencies of natural oscillations of a reinforced concrete clamped beam were considered by Zharnytsky V. I. and Ivanov S. S. [10]. Reinforced concrete beam clamped at one end and hinged at the other; the ratio of elastic moments, deflections and frequencies of natural oscillations are also given in the work of Ivanov S. S. [11].

\section{PURPOSE AND OBJECTIVES OF THE RESEARCH}

The purpose of this work is analytical, experimental and numerical determination of natural frequencies and forms of oscillations of reinforced concrete and fiber concrete beams.

To achieve this goal it was necessary to solve the following tasks:

1. Analyze modern analytical, numerical and experimental methods for studying the dynamics of reinforced concrete and fiber concrete beams.

2. Solve analytically the problem of determining the natural frequencies and forms of oscillations of reinforced concrete and fiber concrete beams.

3. Perform computer modeling of the considered structures and develop a method of their modal analysis based on the finite element method.

4. Perform experimental studies of free oscillations of the considered structures and comparative analysis of all obtained results.

\section{RESEARCH RESULTSS}

Experimental and analytical determination of natural frequencies and oscillation forms of reinforced concrete and fiber concrete beams.

A series of reinforced concrete and reinforced concrete beams with the same reinforcement by rod reinforcement was made in the laboratory of the Department of Structural Mechanics of Odesa state academy of civil engineering and architecture (Fig. 1).
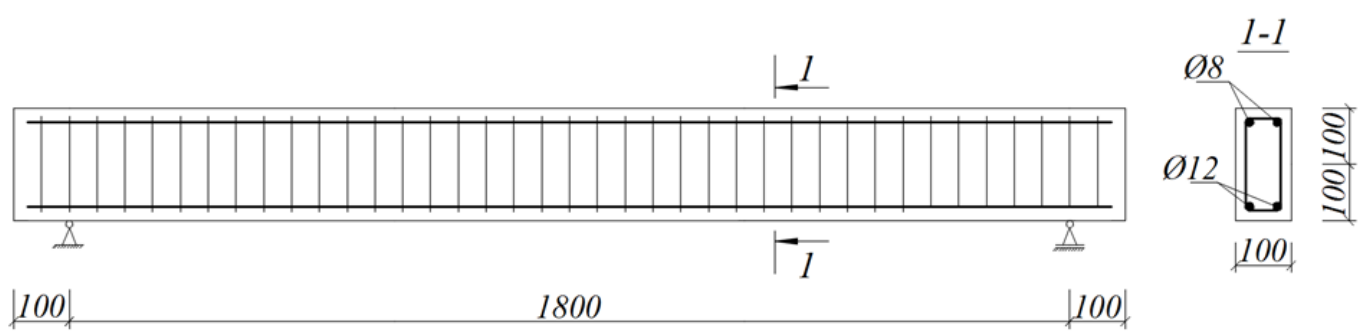

Fig. 1. Reinforcement of beams by rod reinforcement 
Previously completed studies, during which the optimum characteristics of fibrous concrete mixture were determined and tests were performed to determine the mechanical properties of concrete and fiber concrete.

To do this, the cubic strength of concrete and reinforced concrete was determined on samples of 100x100x100 mm. The percentage of dispersed reinforcement varied and was 0,5 $\%, 1,0 \%$ and $1,5 \%$, also fraction of coarse aggregate (crushed stone) was $\leq 10 \mathrm{~mm}$ in one testing series and $\leq 20 \mathrm{~mm}-$ in second. At the same time, the cubic strength of ordinary concrete at the same size of large aggregate was determined. A total of 8 series of tests were performed on 9 samples each.

The experiments used steel fiber (Fig. 2) with curved ends, which is produced by the Ukrainian association "Stalkanat-Silur" in accordance with the European standard EN 148891: 2006 [12].

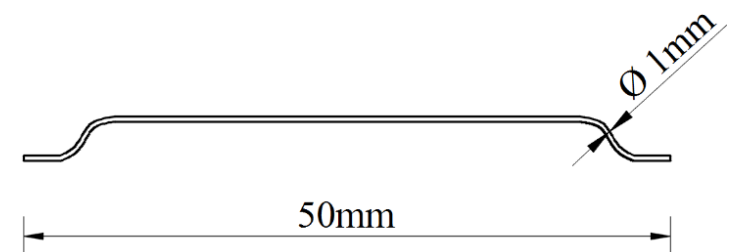

Fig. 2. Steel fiber with curved ends

Processing of the results of this test stage showed that the optimal characteristics of the fiber concrete mixture is a matrix with a large aggregate of $10 \mathrm{~mm}$ (the cubic strength was significantly higher than the size of crushed stone $10 \mathrm{~mm}$ in all series of experiments) at $1.0 \%$ fiber reinforcement, because the higher the percentage of fiber reinforcement, the increase in cubic strength was insignificant. This composition of the mixture was adopted for the manufacture of beams.

Plot of $\sigma-\varepsilon$ is shown in Fig. 3.

In the first section, the diagram is linear, so the tangent of the angle of inclination to the horizontal axis is the initial modulus of elasticity.

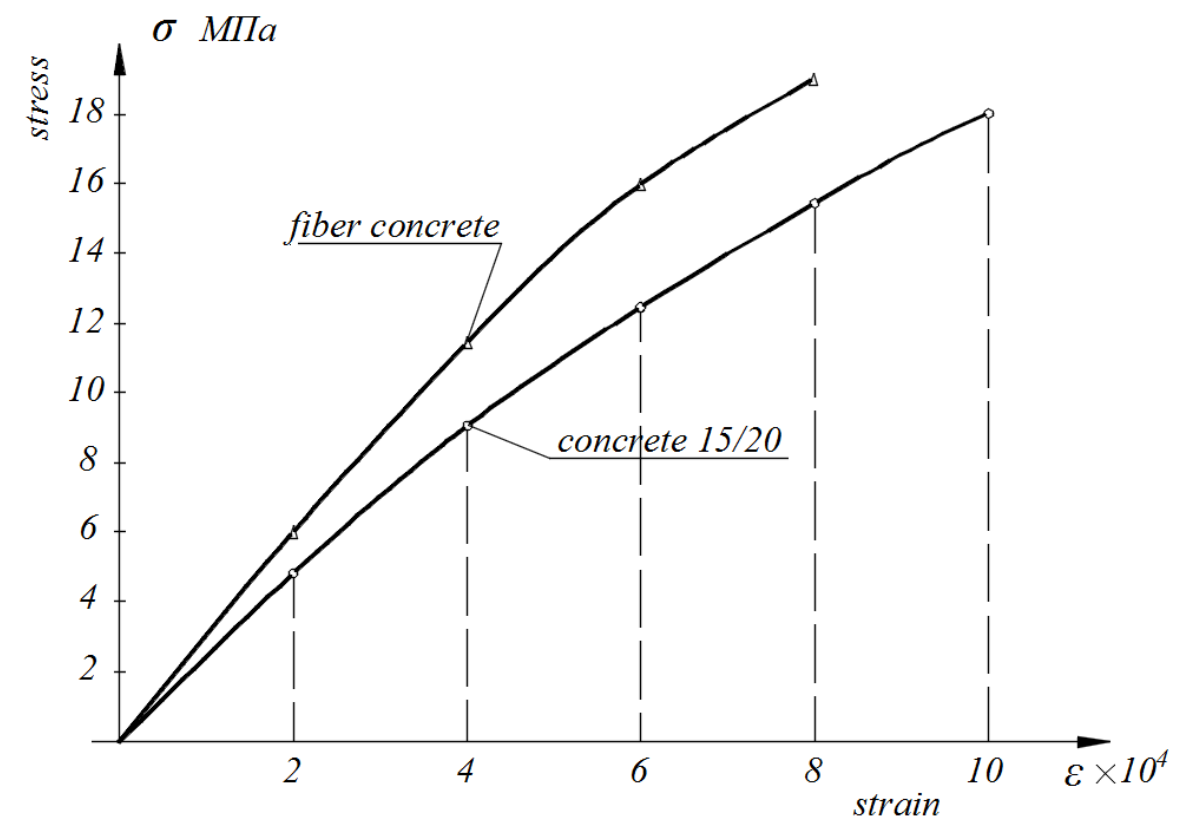

Fig. 3. Plot $\sigma-\varepsilon$

Analytical values of frequencies are calculated by known formulas of classical dynamics $[13,14]$. 
To conduct experimental research, a test bench $M O D A L-2$, was developed, the general scheme of which and the principle of operation are described in detail in our previous works $[15,16]$.

Table 1 shows experimental and analytical data on the first three frequencies for concrete and reinforced concrete beams. The natural frequencies determined experimentally are significantly higher than the theoretical ones.

Table 1

Experimental and analytical results.

\begin{tabular}{|l|c|c|c|c|}
\hline Material & Frequency, $^{-1}$ & Experiment & Calculation & Discrepancy, \% \\
\hline \multirow{4}{*}{ Concrete } & $\omega_{1}$ & 979,23 & 826,74 & 15,6 \\
\cline { 2 - 5 } & $\omega_{2}$ & 4032,80 & 3306,98 & 18,0 \\
\cline { 2 - 5 } & $\omega_{3}$ & 9420,23 & 7440,70 & 21,0 \\
\hline \multirow{3}{*}{$\begin{array}{l}\text { Fiber concrete, } \\
1,0 \%\end{array}$} & $\omega_{1}$ & 1071,96 & 898,76 & 16,1 \\
\cline { 2 - 5 } & $\omega_{2}$ & 4419,03 & 3595,05 & 18,6 \\
\cline { 2 - 5 } & $\omega_{3}$ & 10214,62 & 8088,87 & 20,8 \\
\hline
\end{tabular}

\section{Computer modeling and finite element modal analysis}

Four computer complexes - LIRA-CAD [17], SCAD [18], ANSYS [19] and SOFiSTiK [20] were used for computer modeling of reinforced concrete and fibroconcrete beams and further determination of natural frequencies and forms of oscillations.

Based on them, computer models of concrete and fiber concrete beams with the same reinforcement with rod reinforcement were built.

Fig. 4 shows the forms of natural oscillations obtained in ANSYS.

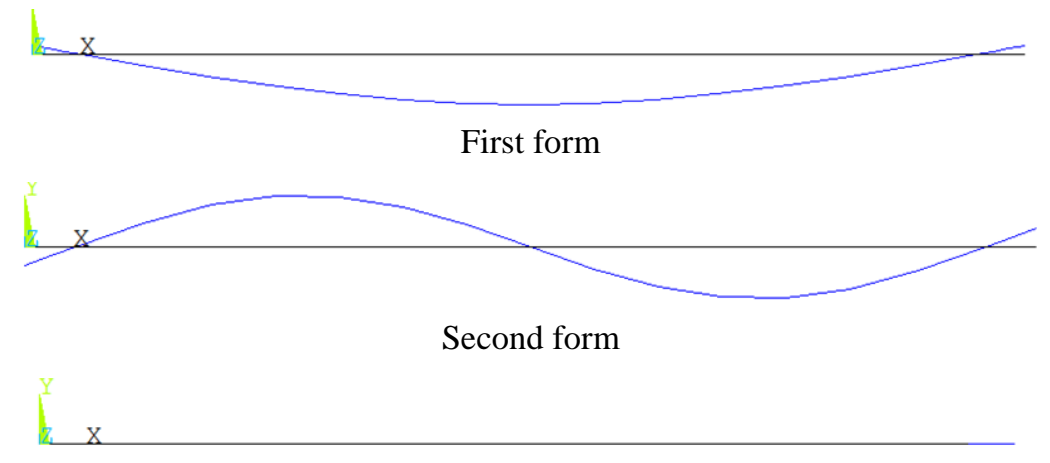

Third form

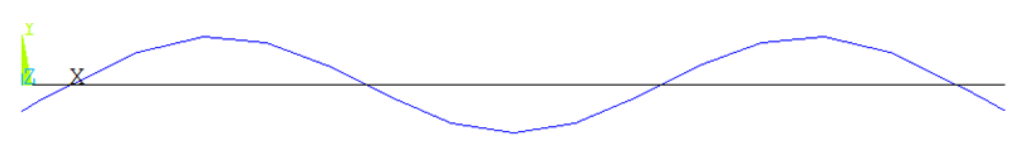

Fourth form

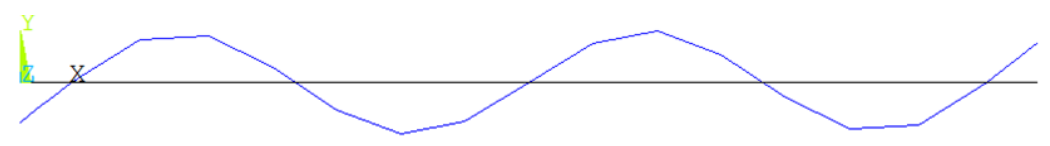

Fifth form

Fig. 4. Forms of natural oscillations obtained in ANSYS

Similar forms of natural oscillations are obtained in three other software packages.

The values of natural frequencies of concrete and fiber-reinforced concrete beams, calculated in four software packages, are given in tables 2,3 . 


\section{Table 2}

Comparison of the results of calculation of natural frequencies of reinforced concrete beam.

\begin{tabular}{|c|c|c|c|c|}
\hline Frequency & LIRA-SAPR & SCAD & ANSYS & SOFiSTiK \\
\hline 1 & 820,82 & 820,82 & 820,08 & 789,25 \\
\hline 2 & 3265,57 & 3259,13 & 3250,14 & 3139,65 \\
\hline 3 & 3860,0 & 3812,40 & 3831,0 & 3711,85 \\
\hline 4 & 7279,58 & 7188,43 & 7209,18 & 7159,29 \\
\hline 5 & 12749,66 & 11364,11 & 12659,30 & 12259,82 \\
\hline
\end{tabular}

Table 3

Comparison of the results of calculation of natural frequencies of the fiber concrete beam.

\begin{tabular}{|c|c|c|c|c|}
\hline Frequency & LIRA-SAPR & SCAD & ANSYS & SOFiSTiK \\
\hline 1 & 867,08 & 867,00 & 866,28 & 833,73 \\
\hline 2 & 3470,50 & 3461,22 & 3455,48 & 3337,06 \\
\hline 3 & 4080,60 & 4021,67 & 4051,64 & 3923,43 \\
\hline 4 & 7808,29 & 77724,56 & 7727,86 & 7507,05 \\
\hline 5 & 13477,53 & 12096,22 & 13386,41 & 12959,54 \\
\hline
\end{tabular}

The above results of calculations were obtained at the initial modulus of elasticity, i.e. correspond to the state of the beams without external load.

Unlike structures made of linearly deformed material, where the modulus of elasticity is assumed to be constant throughout the life cycle of the structure, in reinforced concrete and fiber concrete structures the modulus of elasticity is a variable and decreases with increasing load.

In the first case, when $E=c o n s t$, in classical dynamics, the natural frequency spectrum is considered constant. This spectrum, its own forms of oscillations and attenuation rates are individual characteristics of any system, and do not depend on external influences. All three of these dynamic factors are of paramount importance because they determine the behavior of the system under any other types of oscillations - forced, seismic, parametric.

In the second case, all three parameters are variable, and directly depend on the loads applied to the system. This means that all dynamic calculations of reinforced concrete and fiber concrete structures must be "tied" to a nonlinear deformation diagram.

At the next stage, the first three natural frequencies of oscillations of reinforced concrete and fiber-reinforced concrete beams are analytically calculated taking into account the nonlinear deformation diagram. To do this, the beams were gradually loaded with evenly distributed on the upper surface of the loads to the level of maximum stresses that correspond to the characteristic points of the diagram - deformations $\varepsilon_{1}=2 \cdot 10^{-4}, \varepsilon_{2}=4 \cdot 10^{-4}$, $\varepsilon_{3}=6 \cdot 10^{-4}, \varepsilon_{4}=8 \cdot 10^{-4}, \varepsilon_{5}=10 \cdot 10^{-4}$. Thick metal plates were used as cargoes.

Computer modeling and numerical calculations taking into account the nonlinear diagram of material deformation are performed in two programs.

Their results are given in Table 4 (concrete) and Table 5 (fiber concrete). 
Table 4

The natural frequencies of the reinforced concrete beam at the characteristic points of the diagram.

\begin{tabular}{|c|c|c|c|c|c|c|c|c|}
\hline$E$ & \multicolumn{2}{|c|}{$2,5 \cdot 10^{4} M \Pi a$} & \multicolumn{2}{c|}{$2,25 \cdot 10^{4} M \Pi a$} & $2,05 \cdot 10^{4} M \Pi a$ & \multicolumn{2}{c|}{$1,94 \cdot 10^{4} M \Pi a$} \\
\hline № & LIRA & SOFiSTiK & LIRA & SOFiSTiK & LIRA & SOFiSTiK & LIRA & SOFiSTiK \\
\hline 1 & 761,6 & 732,3 & 505,2 & 485,8 & 430,8 & 414,4 & 263,8 & 253,9 \\
\hline 2 & 2982,0 & 2867,4 & 1978,0 & 1900,1 & 1686,9 & 1624,0 & 1033,0 & 993,3 \\
\hline 3 & 3607,6 & 3468,8 & 2393,0 & 2301,0 & 2040,8 & 1962,3 & 1249,7 & 1202,8 \\
\hline 4 & 6483,8 & 6240,4 & 4300,8 & 3071,4 & 3667,8 & 3530,1 & 2246,1 & 2159,6 \\
\hline 5 & 10859,2 & 10441,3 & 7203,4 & 6923,1 & 6143,1 & 5918,2 & 3761,8 & 3620,6 \\
\hline
\end{tabular}

Table 5

The natural frequencies of the fiber concrete beam at the characteristic points of the diagram.

\begin{tabular}{|c|c|c|c|c|c|c|c|c|}
\hline$E$ & \multicolumn{2}{|c|}{$3 \cdot 10^{4} M \Pi a$} & \multicolumn{2}{c|}{$2,88 \cdot 10^{4} M \Pi a$} & \multicolumn{2}{c|}{$2,67 \cdot 10^{4} M \Pi a$} & \multicolumn{2}{c|}{$2,38 \cdot 10^{4} M \Pi a$} \\
\hline № & LIRA & SOFiSTiK & LIRA & SOFiSTiK & LIRA & SOFiSTiK & LIRA & SOFiSTiK \\
\hline 1 & 662,6 & 637,1 & 520,3 & 501,0 & 419,5 & 403,4 & 252,1 & 242,4 \\
\hline 2 & 2597,3 & 2498,1 & 2052,6 & 1975,6 & 1642,3 & 1580,6 & 1005,9 & 968,1 \\
\hline 3 & 3138,2 & 3014,4 & 2479,5 & 2384,6 & 1986,4 & 1910,0 & 1211,4 & 1165,5 \\
\hline 4 & 5642,2 & 5430,2 & 4463,5 & 4291,8 & 3571,3 & 3433,9 & 2187,0 & 2102,9 \\
\hline 5 & 9455,2 & 9092,3 & 7471,6 & 7191,5 & 5975,6 & 5746,1 & 3658,5 & 3520,7 \\
\hline
\end{tabular}

\section{RESEARCH RESULTS DISCUSSION}

Similar results (quite a significant discrepancy between analytical and experimental data) were obtained by some other authors. Attempts to explain the observed difference by the fact that the analytical formulas for the frequencies of transverse oscillations take into account the moment of inertia of the rod, which in the case of rod reinforcement or dispersed reinforcement must be calculated by special methods, fail. The algorithm for calculating the geometric characteristics of the so-called induced cross section is well known and is given in the numerous literature on reinforced concrete structures, however, based on the formulas of this algorithm, the effect of moment of inertia on oscillations will not be as significant as observed in the experiment.

A more important explanation, in our opinion, is the incorrectness of the used dynamic model of the reinforced beam. The classical dynamics of structures is known to be based on the theory of linear differential equations, and the oscillations of structures are considered with respect to the unstressed initial state.. It is obvious that in the study of free and forced oscillations of reinforced concrete building structures such an approach is unsuitable because they are physically nonlinear systems. There are very few publications on the physically nonlinear dynamics of reinforced concrete structures, and the main attention is paid to methods for solving nonlinear equations of motion, and the concept of determining nonlinear terms of these equations is practically not studied. Numerous experimental researches and computer modeling for the purpose of qualitative and quantitative detection of all factors influencing a spectrum of natural frequencies of fluctuations are necessary here. 


\section{CONCLUSIONS}

Despite the fact that all four software packages implement the finite element method, the process of solving the problem in each of them has its own characteristics, which slightly, but still affect the result. The main ones are: first, different finite elements are involved in different programs; secondly, the processes of construction of a finite-element grid differ and, as a consequence, the number of finite elements with the same geometric model of the structure.

All involved complexes determine the imaginary frequency and imaginary form of oscillations (the third in Fig. 4). This effect is noted in the works of many researchers as one of the disadvantages of the finite element method.

Analysis of the above tables and the results of analytical calculations and experimental data shows the following:

- the frequency spectrum calculated by the finite element method (PC LIRA) is approximately $4 \%$ lower than calculated analytically;

- the results of the calculation in SOFiSTiK differ by $2 \%$ from the results obtained in the PC LIRA;

- the discrepancy with the experimental data reaches $20 \%$, and all frequencies calculated experimentally, higher frequencies calculated analytically or by the finite element method.

\section{References}

1. Gafarova, N. Ye. (2016). Fibrobeton dlya seysmoopasnykh rayonov stroitelstva.[ Fiber concrete for seismic areas of construction]. Mezhdunarodnyy zhurnal prikladnykh $i$ fundamentalnykh issledovaniy. № 9-2. 179-181. [in Russian].

2. Wille, K., El-Tawil, S., Naaman, A.E. (2014). Properties of strain hardening ultra high performance fiber reinforced concrete (UHP-FRC) under direct tensile loading. Cement and Concrete Composites. Vol. 48. 53-66.

3. Kumpyak, O.G., Kokorin, D. N. (2011). Eksperimentalnye issledovaniya zhelezobetonnykh balok na podatlivykh oporakh po naklonnym secheniyam pri kratkovremennom dinamicheskom nagruzhenii. [Experimental researches of reinforced concrete beams on pliable supports on inclined sections at short-term dynamic loading]. Vestnik TGASU. Stroitelnye konstruktsii zdaniya $i$ sooruzheniya. №1. 116-129. [in Russian].

4. Kumpyak, O. G., Galyautdinov, Z. R. (2016). Issledovanie dinamicheskogo deformirovaniya zhelezobetonnykh plit na podatlivykh oporakh. [Investigation of the dynamic deformation of reinforced concrete slabs on yielding supports]. Tomskiy gosudarstvennyy arkhitekturnostroitelnyy universitet. 108-115. [in Russian].

5. Belikov, A. A., Zharnitskiy, V. I. (2011). Uprugoplasticheskie kolebaniya zhelezobetonnykh balok pri deystvii poperechnoy i prodolnoy dinamicheskikh nagruzok. [Elastoplastic vibrations of reinforced concrete beams under the action of transverse and longitudinal dynamic loads]. Vestnik $M G S U$. №2. 145-147. [in Russian].

6. Chaykovskiy, R. E. (2009). Sobstvennye kolebaniya zhelezobetonnykh balok s treshchinami. [Natural vibrations of reinforced concrete beams with cracks]. Sbornik nauchnykh trudov Poltavskogo natsionalnogo tekhnicheskogo universiteta im. Yu. Kondratyuka. Otraslevoe mashinostroenie, stroitelstvo. №. 2. 50-55. [in Russian].

7. SNiP 2.03.01-84*(1996). «Betonnye i zhelezobetonnye konstruktsii». [Concrete and Reinforced Concrete Structures]. M.: TsNIIP Gosstroya RF. [in Russian].

8. Radchenko, P. A., Batuev, S. P., Radchenko, P. A., Plevkov, V. S. (2013). Issledovanie razrusheniya zhelezobetonnykh konstruktsiy pri dinamicheskikh nagruzkakh. [Investigation of the destruction of reinforced concrete structures under dynamic loads]. Tomskiy gosudarstvennyy arkhitekturno-stroitelnyy universitet. T.18. № 4. 1578-1579. [in Russian].

9. Utkin, D. G. (2015). Deformirovanie izgibaemykh stalefibrozhelezobetonnykh elementov so smeshannym armirovaniem pri kratkovremennom dinamicheskom nagruzhenii. [Deformation of bent steel-fiber-reinforced concrete elements with mixed reinforcement under short-term dynamic loading]. Vestnik TGASU. № 5. 80-89. [in Russian]. 
10. Zharnitskiy, V.I., Ivanov, S.S. (2003). Sootnoshenie uprugikh momentov, progiby i chastoty sobstvennykh kolebaniy zhelezobetonnoy zashchemlennoy balki. [Ratio of elastic moments, deflections and natural frequencies of a reinforced concrete restrained beam]. Seysmostoykoe stroitelstvo. Bezopasnost sooruzheniy. № 1. 14-19. [in Russian].

11. Ivanov, S.S. Zhelezobetonnaya balka, zashchemlennaya na odnom kontse i sharnirno opertaya na drugom: sootnoshenie uprugikh momentov, progiby i chastoty sobstvennykh kolebaniy. [Reinforced concrete beam, pinched at one end and pivotally supported at the other: the ratio of elastic moments, deflections and natural vibration frequencies]. Seysmostoykoe stroitelstvo Bezopasnost sooruzheniy. № 1. 17-19. [in Russian].

12. EN 14889-1:2006: Fibres for concrete. Steel fibres. Definitions, specifications and conformity.

13. Babakov, I. M. (2004). Teoriya kolebaniy. [ Oscillation theory]. Ucheb. Posobie. 4-e izd., ispr. Moscow: Drofa. [in Russian].

14. Vasilenko, M. V., Alekseychuk, O. M. (2004). Teoriya kolivan i stiykosti rukhu. [Theory of kolivan and stikosti ruhu]. Kiev: Vishcha shkola. [in Ukranian].

15. Sur'yaninov, M. G., Makovkina, T. S. (2019). Analitichni i eksperimentalni doslidzhennya vilnikh kolivan stalefibrobetonnikh balok. [Analytical and experimental studies of free oscillations of reinforced concrete beams]. Lutsk: Naukovi Notatki. № 66. 351-355. [in Ukranian].

16. Sur'yaninov, M. G., Makovkina, T. S. (2019). Eksperimentalnye issledovaniya svobodnykh kolebaniy zhelezobetonnykh i fibrobetonnykh balok. [Experimental studies of free oscillations of reinforced concrete and fiber concrete beams]. Visnik ODABA, Zbirnik naukovikh prats. №74. 75-81. [in Russian].

17. Gorodetskiy, D. A., Barabash, M. S., Vodopyanov, R.Yu. i dr. (2015). Programmnyy kompleks LIRA-SAPR 2015. [LIRA-CAD 2015 software package]. Uchebnoe posobie pod red. akademika RAASN A.S. Gorodetskogo. Moscow. [in Russian].

18. Semenov, A. A., Startseva, L. V., Malyarenko, A. A., Poryvaev, I. A. (2016). Stroitelnaya mekhanika (spetskurs). Primenenie PK SCAD Office dlya resheniya zadach dinamiki i ustoychivosti sterzhnevykh sistem. [Construction mechanics (special course). Application of SCAD Office PC for solving problems of dynamics and stability of rod systems]. Moskva: Izd-vo SKAD SOFT: Izd. Dom ASV. [in Russian].

19. Lazareva, D. V., Soroka, M. M., Shilyaev, O. S. (2020). Priyomi roboti z PK ANSYS pri rozv'yazanni zadach mekhaniki. [Techniques of working with ANSYS PC when solving mechanics problems]. Pid redaktsieyu M.G. Sur'yaninova: monografiya. Odesa: ODABA. [in Ukranian].

20. Kukhtin, V. N., Bulaev, I. V., Baranov, I.S. (2015). Primenenie raschetnogo kompleksa SOFiSTiK dlya rascheta mostovykh konstruktsiy: uchebnoe posobie. [Application of the SOFiSTiK calculation complex for the calculation of bridge structures: a textbook]. Moskva.: MADI. [in Russian].

\section{Література}

1 Гафарова Н. Е. Фибробетон для сейсмоопасных районов строительства. Международный журнал прикладных и фундаментальных исследований, 2016. № 9-2. С. 179-181.

2 Wille K., El-Tawil S., Naaman A.E. Properties of strain hardening ultra high performance fiber reinforced concrete (UHP-FRC) under direct tensile loading. Cement and Concrete Composites. 2014. Vol. 48. pp. 53-66.

3 Кумпяк О. Г., Кокорин Д. Н. Экспериментальные исследования железобетонных балок на податливых опорах по наклонным сечениям при кратковременном динамическом нагружении. Вестник ТГАСУ. Строительные конструкции здания и сооружения, 2011. №1. C. $116-129$.

4 Кумпяк О. Г., Галяутдинов 3. Р. Исследование динамического деформирования железобетонных плит на податливых опорах. Томский государственный архитектурностроительный университет, 2016. С. 108-115.

5 Беликов А. А., Жарницкий В. И. Упругопластические колебания железобетонных балок при действии поперечной и продольной динамических нагрузок. Вестник МГСУ, 2011. №2. C. 145-147. 
6 Чайковский Р. Э. Собственные колебания железобетонных балок с трещинами. Сборник научных трудов Полтавского национального технического университета им. Ю. Кондратюка. Отраслевое машиностроение, строительство, 2009. Вып. 2. С. 50-55.

7 СНиП 2.03.01-84* «Бетонные и железобетонные конструкции». М.: ЦНИИП Госстроя РФ, 1996.

8 Радченко П. А., Батуев С. П., Радченко П. А., Плевков В. С. Исследование разрушения железобетонных конструкций при динамических нагрузках. Томский государственный архитектурно-строительный университет, 2013 Т.18. Вып.4. С. 1578-1579.

9 Уткин Д. Г. Деформирование изгибаемых сталефиброжелезобетонных элементов со смешанным армированием при кратковременном динамическом нагружении. Вестник ТГАСУ, 2015. № 5. С. 80-89.

10 Жарницкий В. И., Иванов С. С. Соотношение упругих моментов, прогибы и частоты собственных колебаний железобетонной защемленной балки. Сейсмостойкое строительство. Безопасность сооружений, 2003. № 1. С. 14-19.

11 Иванов С.С. Железобетонная балка, защемленная на одном конце и шарнирно опертая на другом: соотношение упругих моментов, прогибы и частоты собственных колебаний. Сейсмостойкое строительство Безопасность сооружений, 2003. № 1. С. 17-19.

12 EN 14889-1:2006: Fibres for concrete. Steel fibres. Definitions, specifications and conformity.

13 Бабаков И.М. Теория колебаний: учеб. пособие. 4-е изд., испр. М.: Дрофа, 2004. 591 с.

14 Василенко М. В., Алексейчук О. М. Теорія коливань і стійкості руху. К.: Вища школа, 2004. $525 \mathrm{c}$.

15 Сур'янінов М. Г., Маковкіна Т. С. Аналітичні і експериментальні дослідження вільних коливань сталефібробетонних балок. Наукові Нотатки. Вип. 66. Луцьк, 2019. С. 351-355.

16 Сурьянинов Н. Г., Маковкина Т. С. Экспериментальные исследования свободных колебаний железобетонных и фибробетонных балок. Вісник ОДАБА. Збірник наукових праць, №74. 2019. С. 75-81.

17 Городецкий Д. А., Барабаш М. С., Водопьянов Р. Ю. и др.Программный комплекс ЛИРАСАПР 2015. Учебное пособие под ред. академика РААСН А. С. Городецкого. М., 2015. $376 \mathrm{c}$.

18 Семенов А. А., Старцева Л. В., Маляренко А. А., Порываев И. А. Строительная механика (спецкурс). Применение ПК SCAD Office для решения задач динамики и устойчивости стержневых систем. Москва: Изд-во СКАД СОФТ: Изд. Дом АСВ, 2016. 255 с.

19 Лазарєва Д. В., Сорока М. М., Шиляєв О. С. Прийоми роботи з ПК ANSYS при розв'язанні задач механіки. Під редакцією М.Г. Сур'янінова: монография. Одеса: ОДАБА, 2020. 432 с.

20 Кухтин В. Н., Булаев И. В., Баранов И. С. Применение расчетного комплекса SOFiSTiK для расчета мостовых конструкций: учебное пособие. М.: МАДИ, 2015. 136 с.

\section{Tatiana Makovkina}

Odessa State Academy of Civil Engineering and Architecture, postgraduate

Didrihsona str., 4, Odessa, Ukraine 65029tata.makovkina1993@gmail.com

ORCID: 0000-0002-2628-5724

\section{Mykola Surianinov}

Odessa State Academy of Civil Engineering and Architecture, Doctor of Technical Science, Professor

Didrihsona str., 4, Odessa, Ukraine 65029, sng @ ogasa.org.ua, ORCID: 0000-0003-2592-5221

Olexsander Chuchmai

Odessa State Academy of Civil Engineering and Architecture, Ph.D., Senior Lecturer

Didrihsona str., 4, Odessa, Ukraine 65029, alexsandrch14061983@ gmail.com

ORCID: 0000-0002-5856-623X

For references:

Makovkina T., Surianinov M., Chuchmai O. (2021). Modal analysis of reinforced concrete and fiber concrete beams. Mechanics and Mathematical Methods. 3 (1). 95-105

Для посилань:

Маковкіна Т. С., Сур'янінов М. Г., Чучмай О. М. Модальний аналіз залізобетонних та фібробетонних балок. Механка та математичні методи, 2021. Том 3. Вип. 1. С. 95-105 